\title{
LANDSCAPE AND LIMNOLOGICAL RESEARCH OF LAKE SYSTEMS OF THE PLAIN AREAS OF THE NORTHEASTERN BORDERLANDS OF THE REPUBLIC OF KAZAKHSTAN AND ASSESSMENT OF THEIR RECREATIONAL CAPACITY
}

\author{
Tatyana V. NAZAROVA \\ L.N. Gumilyov Eurasian National University, Department of Physical and \\ Economic Geography, Astana, Republic of Kazakhstan, e-mail: tvnazarova81@mail.ru
}

\section{Ivan A. FOMIN}

Tyumen State University, Institute of Earth Sciences, Department of Geoecology, Osipenko St. 2, Tyumen, Russian Federation, e-mail: iafomin@mail.ru

\section{Pavel S. DMITRIYEV}

M. Kozybayev North Kazakhstan State University, Department of Geography and Ecology, Pushkin St. 86, 150000, Petropavlovsk, Republic of Kazakhstan, e-mail: pdmitriev@mail.ru

\author{
Jan A. WENDT* \\ Gdańsk University, Faculty of Oceanography and Geography, Institute of Geography, \\ Bażyńskiego St. 4, 80-309 Gdańsk, Poland, e-mail: jan.wendt@ug.edu.pl
}

\section{Kulchikhan M. JANALEYEVA}

L.N. Gumilyov Eurasian National University, Department of Physical and Economic Geography, Astana, Republic of Kazakhstan, e-mail: dzhanaleeva44@mail.ru

\begin{abstract}
Citation: Nazarova, T.V., Fomin, I.A., Dmitriev, P.S., Wendt, J.A., \& Janaleyeva, K.M. (2019). LANDSCAPE AND LIMNOLOGICAL RESEARCH OF LAKE SYSTEMS OF THE PLAIN AREAS OF THE NORTHEASTERN BORDERLANDS OF THE REPUBLIC OF KAZAKHSTAN AND ASSESSMENT OF THEIR RECREATIONAL CAPACITY. GeoJournal of Tourism and Geosites, 25(2), 485-495. https://doi.org/10.30892/gtg.25217-375
\end{abstract}

\begin{abstract}
The article is concerned with landscape and limnological research of lake systems in the plain areas of the Republic of Kazakhstan. The results obtained present field expeditionary, landscape and limnological research, primarily of the plain areas of the northeastern borderlands of the Republic of Kazakhstan. A genetical classification of lake basins in key areas, as a single natural complex, based on the main features of environmental conditions in the research area is given. The hydrological and hydrochemical data of lake systems (temperature, transparency and color of water, $\mathrm{pH}$ value, content of oxygen dissolved in water and $\mathrm{BOD}_{5}$ of biochemical oxygen demand) are determined. An assessment of the recreational capacity of lakes in the region is given. The created electronic geodatabase is open to replenish it with miscellaneous information (from paleogeographic data to modern results of environmental monitoring) and can serve as the basis for
\end{abstract}

\footnotetext{
* Corresponding author
} 
Tatyana V. NAZAROVA, Ivan A. FOMIN, Pavel S. DMITRIYEV, Jan A. WENDT, Kulchikhan M. JANALEYEVA

creating a multi-purpose cadastre of reservoirs, as well as for justifying balanced nature resource management schemes in the areas covered with lakes.

Key words: landscape, lake system, lake classification, recreational capacity.

\section{INTRODUCTION}

The plain areas of the northeastern borderlands of the Republic of Kazakhstan include the North-Kazakh, Yessil, as well as the Kulyndy plains and the southern borderlands of the Baraba steppe. The study of problems associated with the dynamics of large lakes and lake-flowing systems in the areas of the Republic of Kazakhstan plays a special role in modern geographical science.

One of such areas, whose dynamics depends on the state of lake systems, are the plains of the northeastern borderlands of the Republic of Kazakhstan. The research of lake systems of plain areas of the northeastern borderlands of the Republic of Kazakhstan is of interest primarily because the accumulation of lakes of various sizes with varying composition of water in a fairly compact area with close climatic and geological and geomorphological conditions allows a more reliable assessment of the role of the main factors controlling the diversity of the composition natural waters.

\section{RESEARCH MATERIALS AND METHODS}

Many limnology scientists (Popolzin, 1960, 1965, 1967; Filonets, 1974, Beletskaya, 1976, 1987; Kolomin, 2004) have researched the lakes of Northern Kazakhstan.

The landscape and limnological research algorithm includes three stages: 1) preparatory (pre-field) period (selection and analysis of cartographic, satellite and aerial photographs; selection of representative catchments and preparation of a topographic base of 1:25 000 - 1: 10 ooo scale; preliminary interpretation of satellite and aerial photographs; 2) field period (instrumental measurements, water temperature measurement, water sampling, analysis of species diversity of hydrophytes; 3) office period (laboratory analyzes of water and vegetation samples; compilation of information, assessment of the recreational capacity of the lake areas).The conducted landscape research presents the results of the analysis of thematic maps, statistical data, informational analytical material, professional literature, Landsat 8 satellite photographs, field research data (2017-2018), topographic maps of $1: 200000$ scales during which 7 key areas were surveyed. Spatial analysis and synthesis of data were performed using the ArcGIS 10.4.1 geographic information system.

Observations were made at key areas and their physiographic description was given. Samples of water from reservoirs, watercourses were collected using the point method. Water was taken from a depth of $0.15-0.25 \mathrm{~m}$ into plastic containers with a volume of 5 liters, in accordance with the requirements for sampling, primary processing, and storage of samples of natural waters. Under field conditions, the following organoleptic properties of water were determined: color (color value), transparency (turbidity), smell. Chemical and analytical research of selected samples were performed in certified laboratories of the Branch of the Republican State Enterprise on the Right of Economic Management "National Centre of Expertise" of the Public Health Protection Committee of the Ministry of Healthcare of the Republic of Kazakhstan in the North Kazakhstan region in accordance with approved methods. 
Landscape and Limnological Research of Lake Systems of the Plain Areas of the Northeastern

Borderlands of the Republic of Kazakhstan and Assessment of Their Recreational Capacity

To determine the pigment characteristics of phytoplankton, water samples were taken during the period of maximum development of phytoplankton from the surface layer. Samples were concentrated by filtering water from a volume of $300-400 \mathrm{ml}$ through membrane filters "Vladipor" MFAS-OS-3 with a pore diameter of $0.8 \mu \mathrm{m}$. To assess the content of organic matter in the reservoir by zooplankton and macrophytes, the Pantle-Buck saprobity index (S) in Sladechek's modification was calculated using the formula 1:

$$
S=\sum s_{i} \square h_{i} / \sum h_{i}
$$

where $\mathrm{si}_{\mathrm{i}}$ - indicator value of species in sample; $\mathrm{h}_{\mathrm{i}}$ - number of species in sample;

Table 1. Assessment of Recreational Properties of a Water Body for Mass Recreation

\begin{tabular}{|c|c|c|c|c|c|c|}
\hline \multirow{2}{*}{$\begin{array}{l}\text { Property of } \\
\text { water body }\end{array}$} & \multicolumn{5}{|c|}{$\begin{array}{l}\text { Quantitative characteristic of parameter of water } \\
\text { body properties indicator (ki), score }\end{array}$} & \multirow{2}{*}{\begin{tabular}{|c|} 
Weight \\
coefficient of \\
indicator $\left(\mathrm{a}_{\mathrm{i}}\right)$
\end{tabular}} \\
\hline & 1 & 2 & 3 & 4 & 5 & \\
\hline $\begin{array}{l}\text { Bottom of } \\
\text { reservoir }\end{array}$ & $\begin{array}{l}\text { Muddy } \\
\text { and peaty }\end{array}$ & Argillaceous & Rocky & Gravelly & Sandy & 0,12 \\
\hline $\begin{array}{c}\text { Width of shallow } \\
\text { water, } \mathrm{m}\end{array}$ & 50 & 40 & 30 & 20 & 10 & 0,08 \\
\hline $\begin{array}{l}\text { Quality of } \\
\text { water }\end{array}$ & $\begin{array}{l}\text { Visible } \\
\text { pollution }\end{array}$ & $\begin{array}{l}\text { Containing } \\
\text { smells }\end{array}$ & $\begin{array}{l}\text { Within } \\
\text { normal limits }\end{array}$ & $\begin{array}{c}\text { Within norma } \\
\text { limits for } \\
\text { drinking water } \\
\text { supply }\end{array}$ & \begin{tabular}{|c|} 
Exceptionally \\
clean spring \\
water \\
reservoirs
\end{tabular} & 0,15 \\
\hline $\begin{array}{l}\text { Area of coastal } \\
\text { cultural zone, } \\
\mathrm{m}^{2} / \text { person }\end{array}$ & 17 & 18 & 19 & 20 & 21 & 0,15 \\
\hline $\begin{array}{c}\text { Near-stream } \\
\text { vegetation }\end{array}$ & $\begin{array}{l}\text { Swamp and } \\
\text { with sparse } \\
\text { shrubbery }\end{array}$ & $\begin{array}{l}\text { Low forest } \\
\text { and spruce } \\
\text { forests }\end{array}$ & $\begin{array}{l}\text { Meadow } \\
\text { vegetation }\end{array}$ & Mixed forest & $\begin{array}{l}\text { Light pine } \\
\text { forests }\end{array}$ & 0,1 \\
\hline $\begin{array}{l}\text { Aesthetics of } \\
\text { landscapes }\end{array}$ & $\begin{array}{c}\text { Weak } \\
\text { expressiveness } \\
\text { of terrain }\end{array}$ & $\begin{array}{l}\text { Monotonous } \\
\text { landscape }\end{array}$ & $\begin{array}{l}\text { Expressive } \\
\text { landscape }\end{array}$ & $\begin{array}{c}\text { Scenic } \\
\text { landscape } \\
\text { views }\end{array}$ & $\begin{array}{c}\text { Bright } \\
\text { multi-scenic } \\
\text { landscape views }\end{array}$ & 0,12 \\
\hline $\begin{array}{c}\text { Area of waters, } \\
\mathrm{m}^{2} / \text { person }\end{array}$ & Less than $5^{\circ}$ & 60 & 70 & 80 & 90 & 0,08 \\
\hline Aquatic fauna & $\begin{array}{l}\text { Poor species } \\
\text { and low value } \\
\text { ichthyofauna } \\
\text { composition }\end{array}$ & $\begin{array}{l}\text { Ichthyopro- } \\
\text { ductivity of } \\
5-15 \mathrm{~kg} / \mathrm{ha}\end{array}$ & $\begin{array}{l}\text { Commercial } \\
\text { species with } \\
\text { productivity } \\
\text { of } 30 \mathrm{~kg} / \mathrm{ha}\end{array}$ & $\begin{array}{c}\text { Rational } \\
\text { composition of } \\
\text { ichthyofauna }\end{array}$ & $\begin{array}{c}\text { Valuable fish } \\
\text { species }\end{array}$ & 0,1 \\
\hline $\begin{array}{c}\text { Historical and } \\
\text { cultural } \\
\text { monuments }\end{array}$ & $\begin{array}{l}\text { Lack of } \\
\text { showplaces }\end{array}$ & $\begin{array}{c}\text { Ordinary } \\
\text { monuments }\end{array}$ & $\begin{array}{c}\text { More } \\
\text { significant } \\
\text { monuments }\end{array}$ & $\begin{array}{c}\text { Monuments } \\
\text { of great } \\
\text { artistic value }\end{array}$ & $\begin{array}{l}\text { Monuments } \\
\text { protected } \\
\text { by law }\end{array}$ & 0,05 \\
\hline $\begin{array}{c}\text { Improvement } \\
\text { level }\end{array}$ & $\begin{array}{c}\text { Minor } \\
\text { improvement }\end{array}$ & $\begin{array}{c}\text { Additional } \\
\text { improvement } \\
\text { of beaches }\end{array}$ & $\begin{array}{l}\text { Additional } \\
\text { catering } \\
\text { facilities }\end{array}$ & $\begin{array}{c}\text { Overnight } \\
\text { accommodation }\end{array}$ & $\begin{array}{l}\text { Capital } \\
\text { facilities }\end{array}$ & 0,05 \\
\hline
\end{tabular}

The temperature, transparency and color of water, the $\mathrm{pH}$ value, the content of oxygen and $\mathrm{BOD}_{5}$ (biochemical oxygen demand) dissolved in water were determined by the Winkler method. Hydrochemical analysis was performed on 12 elements $\left(\mathrm{CO}_{2}{ }_{2}\right.$, $\mathrm{HCO}_{3}, \mathrm{Cl}-\mathrm{SO}_{4}{ }^{2-}, \mathrm{Ca}^{2+}, \mathrm{Mg}^{2+}, \mathrm{Na}^{+}, \mathrm{pH}, \mathrm{NO}_{2}{ }^{-}, \mathrm{NO}_{3}{ }^{-}, \mathrm{NH}_{4}{ }^{+}, \mathrm{P}^{-} \mathrm{PO}_{4}{ }^{3-}$ ), and also to study hardness and total dissolved solids. Sampling and processing of samples was performed according to the standard method [Abakumov, 1992]. In addition to field research, data 
from physical and geographical research of lakes in the region were systematized according to archive and cartographic materials (S 1:25 000). Polish geographers (Kostrowicki, 1970; Warszyńska, 1972; 1974; Wyrzykowski, 1985; Zwoliński, 1992; Rychling, 2010) are responsible for determining the optimal recreational loads on natural landscapes. To assess the level of recreational capacity of water bodies, we used materials (Herman \& Wendt, 2011; Ilieş et al., 2018) and used a composite quality indicator calculated by the method of weighted average calculation (Gubiy, 2005).

$$
k=\sum k_{i} \sum a_{i}
$$

where $k_{i}$ - indicator of the $i$ property of water body, scores; $a_{i}$ - weight coefficient of the $k_{i}$ indicators, unit fraction $\left(\sum a_{i}=1\right)$ (Table 1$)$.

\section{RESULTS AND DISCUSSION}

The essence of the research is described on the example of key areas, the choice of which is due to the different genesis of the lake basins, since the origin of the lake basin determines the main typical features of the lake. Within the region under study, as a result of field research in 2018, seven key areas are highlighted (Figure 1).

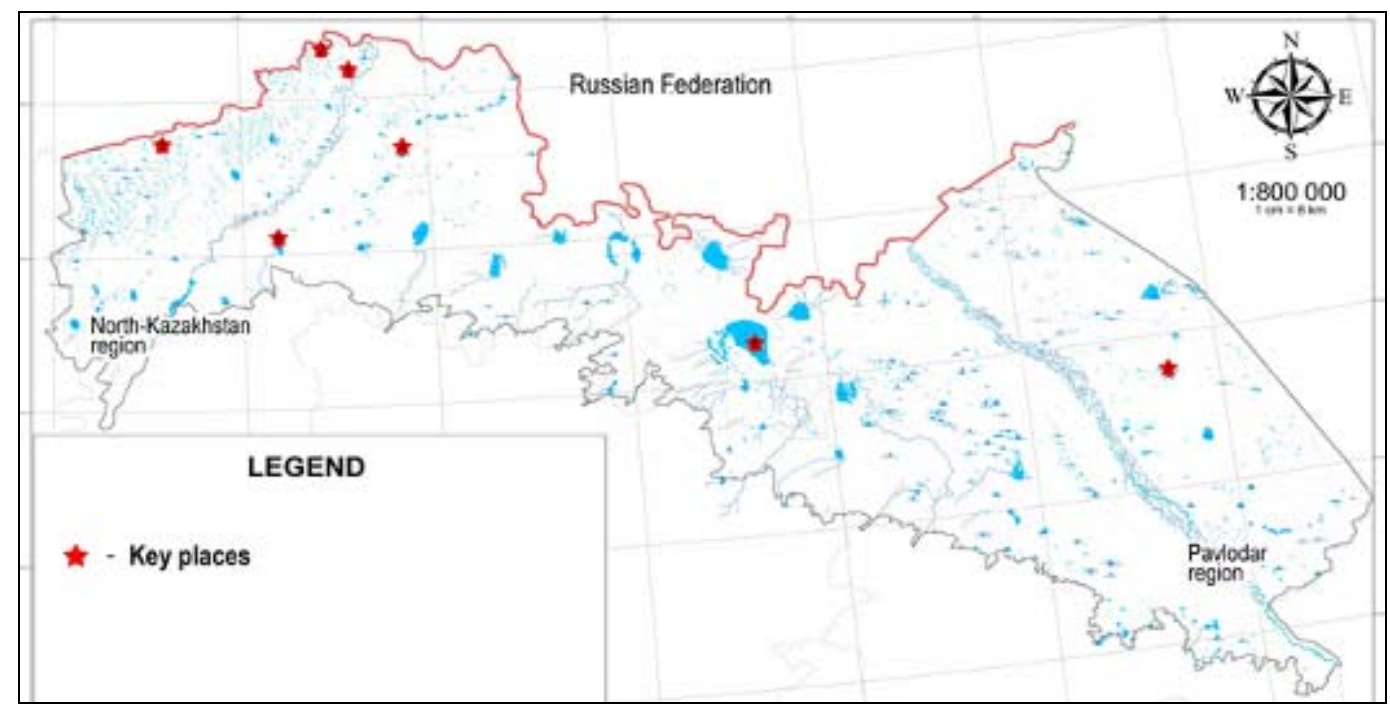

Figure 1. Diagrammic Map of Key Areas of Summer Field Research in 2018

The size and shape of the lake basins are closely related to the origin (genesis) of the lake basins and, therefore, the regime of the lakes. A number of characteristics can relatively easily establish the origin of the lake basins: the terrain of the surrounding area, the geological structure and the geological history of the basins.

Therefore, although the genesis of the basins is not an exhaustive characteristic for the description of lakes, it is the basis of the lake classifications. The formation of lake basins as an integral part of the general terrain is the result of all processes that form the terrain of the area as a whole; therefore, to understand the morphology, characteristics of location and origin, it is necessary to consider the general conditions of development, to identify the leading mechanisms for the formation of lake basins. It is also necessary to take into account that lake basins are qualitatively specific landforms, morphology, dimensions, the evolution of which depends on the activity of the water that fills them, the 
Landscape and Limnological Research of Lake Systems of the Plain Areas of the Northeastern

Borderlands of the Republic of Kazakhstan and Assessment of Their Recreational Capacity

volume and level of which, in turn, is determined by general climatic zoning conditions, the catchment morphology and morphometry. Several factors are involved in the formation of the vast majority of lake basins; therefore, genetic classification is based on identifying the factor that guides the creation of each basin. The generalization of materials on the geological structure, geomorphological characteristics of the area allowed us to propose a genetic classification of lake basins of the research area.

Table 1. Genetic classification of Lake Basins and their morphometric data

\begin{tabular}{|c|c|c|c|c|}
\hline Origin & Name of lake & Area, $\mathrm{km}^{2}$ & Depth (max), m & Overgrowth intensity, \% \\
\hline \multicolumn{5}{|c|}{ Hypogene type } \\
\hline \multicolumn{5}{|c|}{ Tectonic } \\
\hline \multirow{3}{*}{ 1. depressions-grabens } & Siletyteniz & 777 & 3,2 & 10 \\
\hline & Mengiser & 33,6 & 2,6 & 8 \\
\hline & Teke & 265 & 6 & 10 \\
\hline 2. depressions-troughs & Shaglyteniz & 240 & 7 & 12 \\
\hline \multicolumn{5}{|c|}{ Exogenous type } \\
\hline \multicolumn{5}{|c|}{ 1. Lakes of ancient valleys } \\
\hline \multirow{2}{*}{ A) Kamyshlovki } & Ulkenzharma & 12,0 & 1,9 & 40 \\
\hline & Balykty & 10,7 & 3,0 & 80 \\
\hline B) Paleo-Sueri & Alpash & 21 & 2,7 & 90 \\
\hline C) Paleo-Yemtsa & Uzynkul & 1,4 & 2,9 & 24 \\
\hline \multicolumn{5}{|c|}{ 2. Lakes of modern valleys } \\
\hline A) floodplain & Pestroe & 1,3 & 3,0 & 15 \\
\hline \multirow{2}{*}{$\begin{array}{l}\text { B) terraces above flood } \\
\text {-plain of Yessil River }\end{array}$} & Alua & 6,4 & 2,5 & 95 \\
\hline & Polkovnikovo & 1,5 & 1,5 & 20 \\
\hline \multicolumn{5}{|c|}{ 3. Residual } \\
\hline Residual & B. Tarangul & 40 & 3,2 & 25 \\
\hline \multicolumn{5}{|c|}{ 4. Lakes between rivers } \\
\hline \multirow{3}{*}{$\begin{array}{l}\text { basin-hilly-low } \\
\text { ridge terrain }\end{array}$} & Sumnoe & 1,73 & 2,9 & 30 \\
\hline & Krugloe & 0,22 & 2,1 & 20 \\
\hline & Pitnoe & 2,0 & 2,6 & 76 \\
\hline \multirow{2}{*}{$\begin{array}{l}\text { Suffosion- } \\
\text { subsidental }\end{array}$} & Obalykul & 1,9 & 2,2 & 50 \\
\hline & Gussinoe & 1,1 & 2,5 & 37 \\
\hline
\end{tabular}

Tectonic:

1) depressions-grabens, as a result of discontinuous tectonic movements, which appeared in the side structures of the West Siberian plate at the neotectonic stage of development (Teke, Kishikaroy, Siletyteniz, Ulkenkaroy, Bolshoy Tarangul, Imantau, Shalkar (Chelkar), Lobanovo, Menkisser, Stanovoe, etc.)

2) depressions-troughs formed as a result of slow oscillating movements without breaking the continuity of rocks (Shaglyteniz, Shelegino, etc.);

Hydrogenic - a result of the activity of flowing water

1) floodplain (oxbow lakes-meanders, oxbow lakes-anabranches, inter-low ridge, secondary floodplain) - numerous lakes of the floodplain of the Yessil River and Yertis River;

2) terraces above floodplain of the valley of Yessil River - basins of the Gorkoe, Lebyazhye, Polkovnikovo, Nikulskikh, Skopino, Alva (Alua), Kendykty lakes, etc.

3) the valleys of the disappeared rivers Kamyshlovka (Balykty, Zhylandy, Bozaral, Taldyaral, Ulkenzharma, Pitnoe, Polovinnoe, Baranovo, Kamyshlovo, Solenoe, etc.), Sueri (Semilovo, Pitnoe, etc.), Kizak, Yemtsa;

4) the basins of the basin-hilly-low ridge terrain - a numerous group formed in the process of forming the terrain mentioned.

Residual - single, preserved ones from the former larger reservoirs. 
Suffosion-subsidental - the most shallow water "flat-bottom steppe depressions", mostly drying up in summer.

Aeolian (theoretically possible) - shallow water produced in sandy and sandy sandy-loam substrates.

Thermokarst (theoretically possible) - shallow water, might appear during the Ice Age due to melting of frozen soil or ice lenses, strongly transformed by subsequent terrainforming processes. The basin, appeared under the influence of one factor, can be further modified by the action of others. The depths and sizes of lakes depend on the genesis of the basins, as shown in Table 1 (Beletskaya, 1987). Thus, the origin of the lake basin to a certain extent leaves its imprint on the individual characteristics of the lake, for example, area, depth, characteristics of slopes, etc. The conducted research allowed creating a landscape map, which demonstrates the space-time patterns that operate in lake systems (Figure 2).

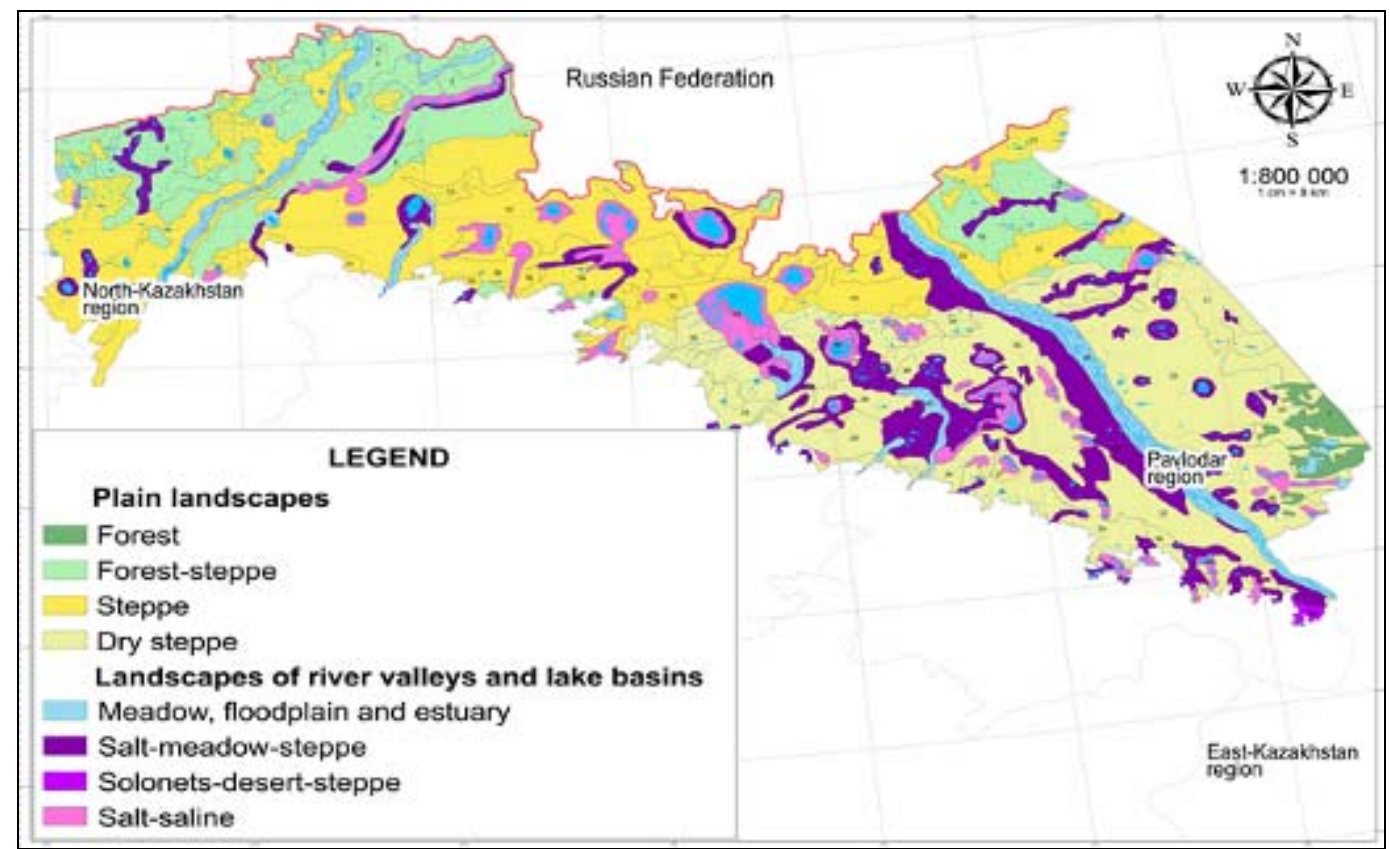

Figure 2. Landscape map of plain areas of northeastern borderlands of the Republic of Kazakhstan

Specific features of the landscape are: 1) plain terrain which is pronounced in the structure of the terrain, developed on ancient sedimentary and eruptive rocks, which alternates with relatively flat areas, confined to ancient and modern valleys, lake basins, where eluvial, deluvial and other friable deposits; 2) prevalence of loess like deposits (loams and sandy loams); 3) prevalence of ancient weathering crusts enclosing bedding rocks; 4) powerful accumulations of river sandy, sandy and pebble alluvium in the valleys of the rivers of the Yessil and Yertis river basin. The functionality of the program ArcGIS 10.4.1 allowed undertaking spatial analysis and data synthesis. As a result of the analysis of thematic maps, statistical data, information analytical material, professional literature, Landsat 8 satellite photographs, field research data (2017-2018), topographic maps of 1:200 ooo scale, morphometric and chemical parameters of the lake systems under research were determined, which are of particular value in fisheries and recreation. In Table 2 and 3, morphometric and chemical information is given on the 7 research reservoirs in key areas and the degree of overgrowth by higher surface vegetation. 
Landscape and Limnological Research of Lake Systems of the Plain Areas of the Northeastern

Borderlands of the Republic of Kazakhstan and Assessment of Their Recreational Capacity

Table 2. Morphometric Data of Some Lakes of North Kazakhstan Region and Degree of Overgrowth by Higher Surface Vegetation

\begin{tabular}{|l|c|c|c|c|c|}
\hline \multirow{2}{*}{ Name of lake } & \multirow{2}{*}{$\begin{array}{c}\text { Area of } \\
\text { lake, } f, \text { ha }\end{array}$} & \multicolumn{2}{|c|}{ Depth, } & \multirow{2}{*}{$\begin{array}{c}\text { Volume of } \\
\text { water mln. } \mathrm{m}^{3}\end{array}$} & $\begin{array}{c}\text { Amount of } \\
\text { overgrowing, \% }\end{array}$ \\
\cline { 3 - 4 } & 600 & 4 & 3 & 18 & $10-15 \%$ \\
\hline Lebyazhye & 680 & 2 & 1,6 & 11 & $5-10 \%$ \\
\hline Yakush & 940 & 1,1, & 0,6 & 6 & $10-15 \%$ \\
\hline Semilovo & 968 & 1,8, & 1,2 & 12 & $15-20 \%$ \\
\hline Ulken-Zharma & 3400 & 4 & 2 & 68 & $10-15 \%$ \\
\hline B. Tarangul & 777750 & 3,2, & 0,7 & 5444 & $5-10 \%$ \\
\hline Siletyteniz & 700 & 40 & 20 & 140 & $30-35 \%$ \\
\hline B. Tavolzhan & & & & \\
\hline
\end{tabular}

Table 3. Chemical Composition of Water in Lakes of North Kazakhstan Region

\begin{tabular}{|c|c|c|c|c|c|c|c|c|c|c|c|}
\hline Lake & $\mathrm{pH}$ & $\begin{array}{l}\text { Oxidizabi- } \\
\text { lity, } \mathrm{mgO} /\end{array}$ & $\begin{array}{l}\mathrm{BOD}_{5}, \\
\mathrm{mgO} / \mathrm{l}\end{array}$ & $\begin{array}{c}\mathrm{NH}_{4}{ }^{+} \\
\mathrm{mg} / \mathrm{l}\end{array}$ & $\begin{array}{l}\mathrm{Ca}^{2+} \\
\mathrm{mg} / \mathrm{l}\end{array}$ & $\begin{array}{c}\mathrm{Mg}^{2+} \\
\mathrm{mg} / \mathrm{l}\end{array}$ & $\begin{array}{c}\mathrm{CL}- \\
\mathrm{mg} / \mathrm{l}\end{array}$ & $\begin{array}{l}\mathrm{SO}_{4}{ }^{2-} \\
\mathrm{mg} / \mathrm{l}\end{array}$ & $\begin{array}{l}\text { Hardness, } \\
\text { mg/equiv }\end{array}$ & $\begin{array}{c}\mathrm{K}+\mathrm{Na} \\
\mathrm{mg} / \mathrm{l}\end{array}$ & $\begin{array}{c}\text { Total dissolved } \\
\text { solids, } \mathrm{g} / \mathrm{l}\end{array}$ \\
\hline 1 & 2 & 3 & 4 & 5 & 6 & 7 & 8 & 9 & 10 & 11 & 12 \\
\hline \multicolumn{12}{|c|}{ Threshold limit value } \\
\hline & $6,5-8.5$ & 10 & 3 & 0,5 & 180 & 100 & 300 & 100 & 14 & 170 & 1.0 \\
\hline Lebyazhye & 7,35 & 8,8 & 4,96 & 0,1 & 66,5 & 124 & 228 & 495 & 16,6 & 741,6 & 2,86 \\
\hline Yakush & 8,38 & 9,6 & 3,23 & 0,02 & 100,4 & 420 & 561,4 & 273,8 & 40 & 3244,8 & 10,3 \\
\hline Semilovo & 8,1 & 9,2 & 4,74 & 0,03 & 123,3 & 363 & 347,9 & 311,2 & 31 & 4863,2 & - \\
\hline Ulken-Zharma & 9,34 & 10,2 & 5,44 & 1,11 & 76,2 & 186,1 & 265,3 & 157,6 & 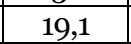 & 1370,9 & \\
\hline L. Tarangul & 8,73 & & 1,6 & 0,08 & 54,3 & 46,6 & 279,3 & 123 & 6,54 & 196,8 & \\
\hline Siletyteniz & 8,2 & 8,7 & 3,16 & 0,07 & 146,8 & 403 & 498,3 & 356,7 & 36 & 5423,1 & \\
\hline $\begin{array}{c}\text { L. Tavolzhan } \\
\text { (brine) } \mathrm{g} \backslash \mathrm{kg}\end{array}$ & 7,8 & 10 & 3,1 & - & 0,843 & 5,5 & 155,2 & 6,924 & 44 & \begin{tabular}{|c|}
0,178 \\
$+92,58$ \\
\end{tabular} & $35-47$ \\
\hline
\end{tabular}

Higher $\mathrm{BOD}_{5}$ rates indicate pollution of natural waters (Figure 3 ). One of the causes of pollution of water bodies with organic substances is the effect of animal husbandry, which practically exists on all lakes; however, all (even drinking) lakes are used for watering animals without special devices for this purpose, and their catchments are used as pastures (except for areas occupied by arable land).

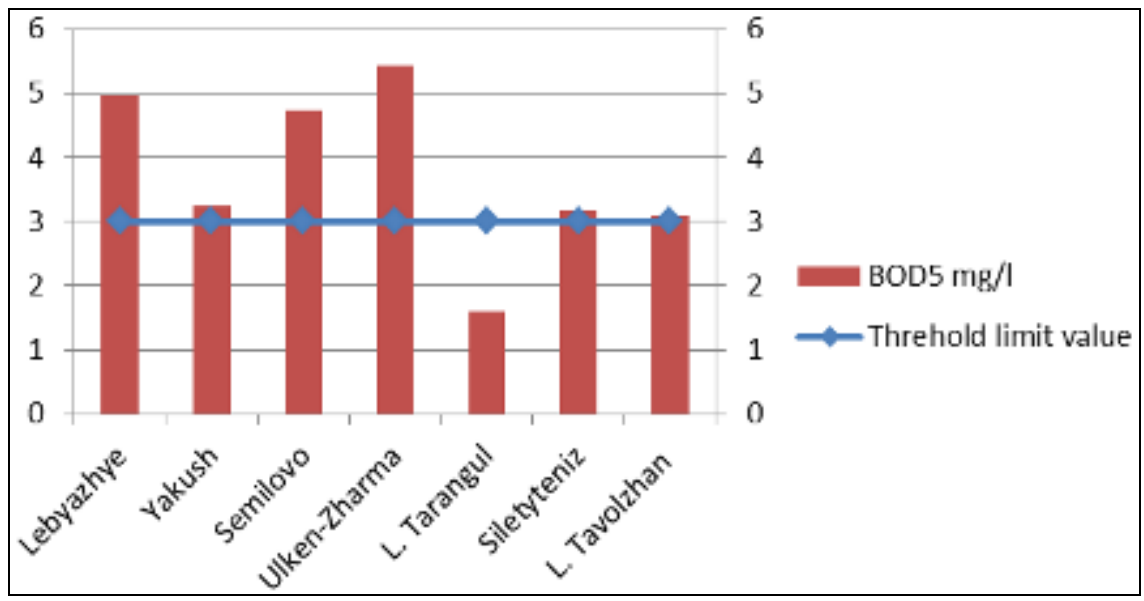

Figure 3. Level of Biochemical Oxygen Demand 
Exceeding the TLV is observed in almost all the reservoirs researched, which indicates the use of lake systems for watering animals without special devices for this purpose, and their catchments - as pastures. Thus, the basin systems of the lakes of the plain part of Kazakhstan are very sensitive to geo-component environmental changes (especially the hydrological regime) due to land-reclamation nature resource management and global climate change. Therefore, quantitative assessments of the parameters of lake systems make it possible to predict environmental natural and anthropogenic risks and threats. An important aspect of our study was the identification of a recreational assessment of lake landscapes, identification of recreational conditions and resources, assessment of their quality and availability, the possibility of using for recreation, health and treatment of the population (Ilieş \& Wendt, 2015; Ilieş et al., 2014, 2017; Gozner, 2016; Gozner \& Avram, 2010; Mazhitova et al., 2018). Undoubtedly, foreststeppe landscapes of plains, floodplain and lake landscapes have all the prerequisites for the development of tourism. Assessment of the recreational properties of the selected water bodies showed that the recreational capacity of the lakes is not the same and varies from 10 to 50 scores. In differentiating recreational properties, we used the following scale: 0-10 - little recreational capacity; 11-20 - low recreational capacity; 21-30 average recreational capacity; more than 31 - high recreational capacity (Table 4, Figure 4).

Table 4. Scoring of Recreational Properties of Lakes of Plain Areas of the Republic of Kazakhstan for Mass Recreation

\begin{tabular}{|c|c|c|c|c|c|c|c|c|c|c|c|}
\hline Lakes & 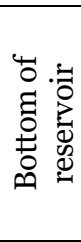 & 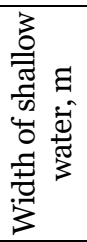 & 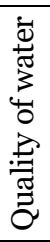 & 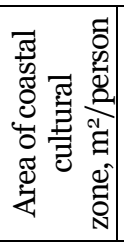 & 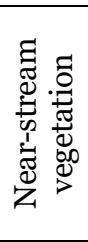 & 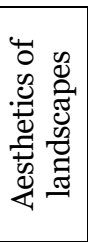 & 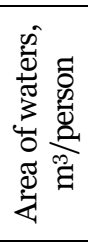 & 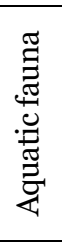 & 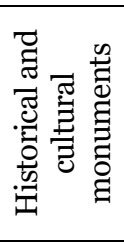 & 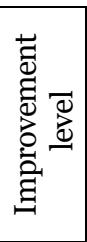 & $\begin{array}{c}\text { Total, } \\
\mathrm{k}_{\mathrm{i}}\end{array}$ \\
\hline Lebyazhye & 3 & 3 & 4 & 5 & 3 & 5 & 2 & 5 & 2 & 5 & 37 \\
\hline Yakush & 2 & 1 & 3 & 2 & 3 & 4 & 2 & 5 & 1 & 1 & 24 \\
\hline Semilovo & 1 & 1 & 2 & 3 & 4 & 4 & 2 & 1 & 1 & 1 & 20 \\
\hline Ulken-Zharma & 1 & 2 & 2 & 5 & 2 & 3 & 1 & 3 & 1 & 2 & 22 \\
\hline L. Tarangul & 3 & 3 & 4 & 5 & 4 & 5 & 2 & 5 & 3 & 5 & 39 \\
\hline Siltyteniz & 1 & 1 & 2 & 1 & 3 & 1 & 5 & 1 & 1 & 1 & 17 \\
\hline \begin{tabular}{|l|} 
L. Tavolzhan \\
\end{tabular} & 1 & 1 & 2 & 1 & 3 & 1 & 5 & 1 & 1 & 1 & 17 \\
\hline
\end{tabular}

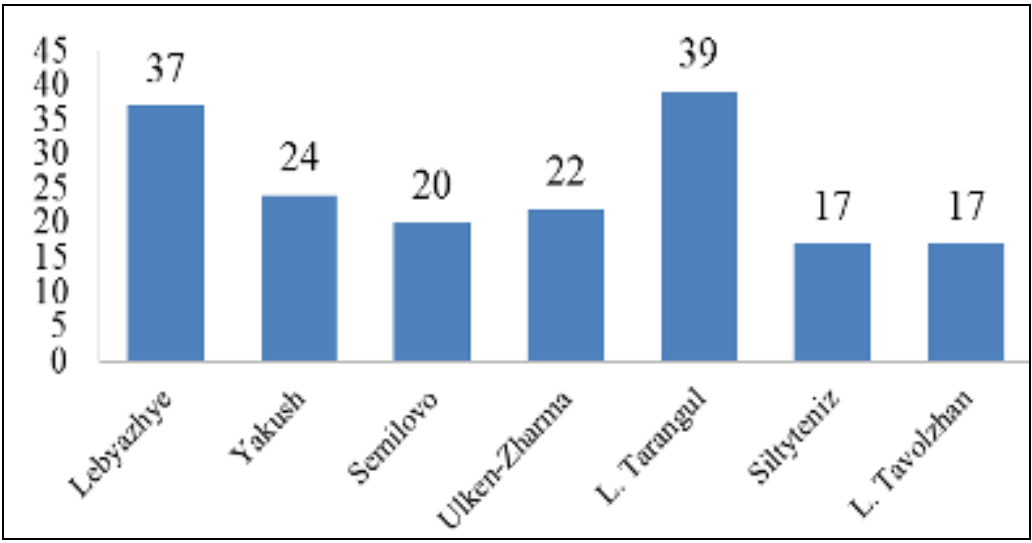

Figure 4. Level of recreational capacity (k) 
Landscape and Limnological Research of Lake Systems of the Plain Areas of the Northeastern

Borderlands of the Republic of Kazakhstan and Assessment of Their Recreational Capacity

The combination of aquatic and forest-steppe geosystems allows for organizing a number of types of recreational activities: beach swimming, hiking and sightseeing recreation, boating, water skiing, hunting for wetland game, fishing, picking berries, mushrooms, useful plants, etc. The development of health resorts is possible on the base of salt lakes and deposits of therapeutic mud, similar to the health resort at the Dear Sea (Wendt, 2016). For the researched lakes, the main season of tourist and recreational activities is the summer period of the year, but in winter skiing, sledding, hunting, ice fishing and other types of recreation are possible here. The off-season is the time for hunting waterfowl. Let's consider in details one of the key areas where the lake system of the Large Tarangul is located. Sampling points on the Large Tarangul lake on the eastern shore were located between the Korneyevka and Sovetskoe villages, on the west bank near the confluence of the Kamysakty River. Physical and chemical properties of water. The water temperature in the lake ranged from $19.8-24.0^{\circ} \mathrm{C}$. The transparency was $0.55^{-0}-60$ $\mathrm{m}$, which, according to the complex classification, corresponds to $2 \mathrm{~b}$, "quite clean" waters. The reaction environment was neutral, the $\mathrm{pH}$ was 7.35-7.45. The specific electrical conductivity corresponded to the TVLw and was $1.73-1.74 \mathrm{mS} / \mathrm{cm}$. The concentration of dissolved oxygen satisfied TVLw and was $7.68-9.92 \mathrm{mg} / \mathrm{dm}^{3}$. The $\mathrm{BOD}_{5}$ was lower than the TVLw and was 1.76-1.92 $\mathrm{mgO}_{2} / \mathrm{dm}^{3}$, which corresponds to $3 \mathrm{~b}$, "low polluted" waters.

According to the magnitude of dissolved solids concentration $\left(1430-1480 \mathrm{mg} / \mathrm{dm}^{3}\right)$, the lake waters belong to $\beta$-mesohaline brackish waters. The salinity of this lake exceeds TVLw. According to the ionic composition in the classification of O.A. Alekin, the lake water belongs to II sodium chloride type of waters. Chlorides $\left(491-526 \mathrm{mg} / \mathrm{dm}^{3}\right)$ predominate among anions, sodium (376-393 mg/dm3) - among cations. The concentration of these ions is 1.5 times higher than the TVLw. The lake water hardness is average, exceeded the TVLw and amounted to $7.04-7.24^{\circ} \mathrm{H}$.

Phytoplankton. The concentration of chlorophyll $a$ in plankton slightly changed in the coastal area and in the open part - from $6.9 \mathrm{mg} / \mathrm{m}^{3}$ to $10.8 \mathrm{mg} / \mathrm{m}^{3}$, which corresponds to the category of oligo-mesotrophic and mesotrophic waters, the quality of water corresponds to Class II, category a and b - "Clean and completely clean." The ratio of carotenoids and chlorophyll a in both sampling points was close to one, which can serve as an indicator of the balance of the biotic balance of the lake ecosystem. The enrichment of the seston with carotenoids is due to the spreading of resuspended dead vegetation residues into the water column. The relative content of the main and auxiliary photosynthetic pigments in their common pool (see Appendix L) is typical of typically limnetic phytoplankton with a predominance of green and diatom algae. The contribution of phaeopigments to the amount with normally functioning chlorophyll did not exceed the most frequently encountered value (30\%) during the summer vegetation period of inland water phytoplankton according to the literary data generalized by V.V. Bulyon.

Phytoperiphyton. In the composition of the phytoperiphyton, developing on the perfoliate pondweed, 13 types of algae from two sections were noted: diatoms $-61.5 \%$, green $-38.5 \%$. Both in terms of number and biomass, the same species dominate in the phytoperiphyton Epithemia sorex Kütz., Ep. turgida (Ehr.) Kütz., Rhopalodia gibba (Ehrb.), Cymbella prostrata (Berk.) Kleve (diatoms), which are indicators of pure water. According to the values of the saprobity index ( 1.8 by number and 1.5 by biomass), the discharge of water quality varies from completely clean (2b) to enough clean (3a). In the range of algae saprobity, pure water indicators dominate (53.8\% of $61.5 \%)$. The Shannon index (3.2 bits/spec. and $2.0 \mathrm{bits} / \mathrm{g}$ ) reflects conditions favorable for algae.

The predominance of oligohalobs in the range of indicators of dissolved solids concentration (53.8\% of $61.5 \%$ ) reflects its low dissolved solids concentration. 
Macrophytes. 10 species of aquatic and coastal aquatic plants from 6 families were found in the lake. Submerged vegetation is represented by communities of the pondweeds (Potamogeton perfoliatus, P.pectinatus, P.lucens, $P$, crispus) and Siberian water-milfoil (Miryophyllum sibiricum), which are widespread in the shallow areas of the lake. It is common to find star duckweed (Lemna trisulca) in these communities. Rigid semisubmerged vegetation forms a border from 50 to $250 \mathrm{~m}$ wide with a projective cover of about $60 \%$ along almost all banks of the reservoir, with the exception of the southern coast, at depths of 1.0-1.5 m. The main cenosis former is common reed (Phragmites australis), along reed beds from the waterside, a separate spot is formed by a water knotweed (Persicaria amphibia (L.) S.F. Gray) and a water crowfoot (Batrachium circinatum (Sibth.). The area of lake overgrowth is $20-25 \%$ in total. The number of reed in communities is 52 spec. $\mathrm{m}^{2}$, production $336 \mathrm{~g} / \mathrm{m}^{2}$ per year, but the value of biomass must be increased by $30 \%$, since only the surface part of the plants was taken during cutting, and, therefore, the biomass formed by reed communities is about $436.8 \mathrm{~g} / \mathrm{m}^{2}$ per year. The saprobity index for macrophytes is 1.66 , which corresponds to the beta-mesosaprobic zone.

Zooplankton. The number of zooplankton reached 299,500 spec./ $\mathrm{m}^{3}$, biomass $1,787.6 \mathrm{mg} / \mathrm{m}^{3}$, due to the mass development of copepods Mesocyclops leuckarti Claus $17 \%$ and rotifers Polyarthra remata Skorikov 52\% and Brachionus angularis Gosse $17 \%$. A very low species diversity of cladocerans is noted. The Pantle-Buck saprobity index was 1.69-1.72. Obviously, in winter the lake is dead. In general, the reservoir is described as $\beta$ mesosaprobic, moderately polluted. The Shannon-Weaver species diversity index ranges from 1.69 to 1.83 bits, i.e. a transformed biocenosis is observed on this lake with the dominance of two or three $\beta$-mesosaprobic species. Zoobenthos. Zoobenthos has 9 species from 4 groups: Oligochaeta, Gastropoda, Trichoptera и Chironomidae.

The lake was described by low indices of number and biomass. In the coastal zone, they varied within $571.4-3428.5 \mathrm{spec} . / \mathrm{m}^{2}, 0.28-0.71 \mathrm{~g} / \mathrm{m}^{2}$, which corresponds to the ultraoligotrophic level of development. Chironomid larvae dominated in numbers: Tanitarsus sp. and Procladius sp. The Goodnight-Whitley index in the coastal area was $8.3 \%$. Thus, the research lakes are located in a densely populated anthropogenic zone, where the main sources of pollution are agricultural and domestic wastewater. The water quality of the reservoir is an integral indicator of the chemical composition of the wastewater effluent from the catchment basin and the self-cleaning capacity of the ecosystem. Self-cleaning capacity of each reservoir depends on the state of living organisms in it.

\section{CONCLUSION}

The obtained quantitative indicators (landscape and limnometric) reflect the current statistics of parameters of the state of lake systems and can serve as the basis of limnological monitoring. In its implementation, it is necessary to widely use modern technologies of geoinformation modeling, ERS data and field research. Further researches include the classification and typification of data and the development of models of balanced nature resource management (water and fisheries, urban and agricultural, recreational, forestry, environmental, etc.) and recommendations for ensuring optimum performance. When analyzing the data obtained, it was found that there are no lakes with a little recreational capacity among the research water bodies, and only such lakes as Siletyteniz, B. Tavolzhan have low recreational capacity. The remaining water bodies have medium and high recreational capacity. The conducted research is important for water management (regional water farms, basin and hydro-amelioration departments), fisheries, recreational institutions. The results can be used to create cadastral (or environmental) passports by regional departments of ecology and natural resources. 
Landscape and Limnological Research of Lake Systems of the Plain Areas of the Northeastern

Borderlands of the Republic of Kazakhstan and Assessment of Their Recreational Capacity

\section{REFERENCES}

Beletskaya N.P. (1971). The Genesis of the Lake Basins of Priishimye. Bulletin of Moscow University. No. 6, pp. 63-68. Beletskaya N.P. (1976). Morphology and morphometry of lake basins of Petropavlovsk Priishimye. Geographical Sciences. Alma-Ata, vol. 6. pp. 67-71.

Beletskaya N.P. (1986). Morphological and morphometric analysis of lake basins (on the example of the West Siberian Plain). Manuscript. Petropavlovsk, 366 p.

Beletskaya N.P. (1987). Genetic classification of lake basins of the West Siberian Plain. Geomorphology, No. 1, pp. 50-58.

Filonets P.P. \& Omarov T.R. (1974). Lakes of North, West, East Kazakhstan. Guide. L., pp. 3-47.

Gozner, M. (2010). Tourism in the Territorial System Albac - Arieseni sistemul teritorial Albac and its impact on the environment. Analele Universităţii din Oradea, Fascicula Construcţii şi Instalaţii Hidroedilitare, vol. XIII - 2, Editura Universităţii din Oradea.

Gozner, M., \& Avram, M. (2010). The situation of the natural reservation from the Territorial System Albac Arieseni. Analele Universităţii din Oradea, Seria Geografie, Tom XX, Editura Universităţii din Oradea; http://journals.indexcopernicus.com/karta.php?action=masterlist\&id=3951.

Gubiy I.G., Pavlinova I.I., Rodin V.N., \& Yakovlev S.V. (2005). Integrated use of water resources: training manual. - M.: The Vysshaya Shkola publishing company, p. 384.

Herman, G.V., \& Wendt, J. A. (2011). Development and promotion of tourism, an extra chance in maintain and assenting the identity and specificity of Oaş land. GeoJournal of Tourism and Geosites, year IV, vol. 7, no. 1, pp. 97-95.

Ilies A. (coord.), Baias S, Baias Iuliana, Blaga L., Buhaș S., Chiriac A., Ciocan Janeta, Dăncuş M., Deac Anca, Dragoș P., Dumitrescu G., Gaceu O., Godea I., Gozner Maria, Grama V., Herman G., Hodor N., Hurley P., Ilieș Dorina, Ilieș Gabriela, Ilieș M., Josan Ioana, Leșe G., Măduța F., Mojolic Diana, Morar C., Olaru M., Stașac M., Stupariu M., Sturza Amalia, Ștefănescu B., Tătar Corina, Vârnav R., Vlaicu M., \& Wendt J.A., (2014), Crisana-Maramures. Atlas geografic al patrimoniului turistic/ Geographical atlas of tourism heritage, 302 pp., Editura Universității din Oradea, ISBN 978-606-10-1298-5.

Ilies A., Hurley Peter D., Ilies D.C., \& Baias S, (2017). Tourist animation -a chance adding value to traditional heritage: case studys in the Land of Maramures (Romania). Revista De Etnografie Si Folclor, New Series 1-2.

Ilieş, A., \& Wendt, J.A., (2015). Tourism geography. The basic of theory and application issues. [Geografia turystyczna. Podstawy teorii i zagadnienia aplikacyjne]. Wydawnictwo AWFiS, Gdańsk.

Ilies, D.C., Buhas, R., Ilies, M., Ilies, A., Gaceu, O., Pop, A.C., Marcu, F., Buhas, S.D., Gozner, M., \& Baias, S. (2018). Sport Activities and Leisure in Nature 2000 Protected Area - Red Valley, Romania. Journal of Environmental Protection and Ecology, 19, No 1, 367-372.

Kolomin Y.M. (2004). Lakes of the North Kazakhstan region: a reference guide. Petropavlovsk, pp. $20-25$.

Kostrowicki, A.S., (1970). Zastosowanie metod geobotanicznych tu ocenie przydatności terenu dla potrzeb rekreacji i wypoczynku [Application of geobotanical methods in appraising fitness of regions for purposes of recreation and rest]. Przegląd Geograficzny, t. XLII, 4, 631-645.

Mazhitova, G.Z., Pashkov, S.V., \& Wendt J.A. (2018), Assessment of landscape ecological - recreational capacity of north Kazakhstan region, GeoJournal of Tourism and Geosites, 11 (3), 731-737.

Popolzin A.G. (1965). Zonal limnological regionalization of lakes in the south of the Ob-Irtysh basin // Issues of hydrology of Western Siberia, Novosibirsk, pp. 52-62.

Popolzin A.G. (1967). Lakes of the Ob-Irtysh basin (Zonal complex characteristic). Novosibirsk, 350 p.

Popolzin A.G., Trifonova T.M. \& Kazanskaya E.A. (1960). Fresh lakes of the Kamyshlovskiy Arroyo. Alma-Ata, pp. 88-156.

Richling A. (2010). Ocena krajobrazu naturalnego Polski dla potrzeb rekreacji [Assessment of the natural landscape of Poland for the needs of recreation], [in:] S. Ciok, P. Migoń (eds.), Przekształcenia struktur regionalnych. Aspekty społeczne, ekonomiczne i przyrodnicze, Wrocław: Instytut Geograficzny i Rozwoju Regionalnego UWr, pp. 391-396.

Warszyńska, J. (1972). Ocena środowieka naturalnego pow. Żywieckiego pod względem sezonowości i ruchu turystycznego [Evaluation of the natural environment Żywiecki county in terms of seasonality and tourist traffic]. Czasopismo Geograficzne, 43, 2, 171-190.

Warszyńska, J. (1974). Ocena zasobów środowiska naturalnego dla potrzeb turystyki (na przykładzie województwa krakowskiego) [Evaluation of natural environment resources for the needs of tourism (on the example of Krakow province]. Zeszyty Naukowe UJ nr 350. Prace Geograficzne, z. 36, Kraków: PWN.

Wendt J.A. (2016). Tourism development challenges on the Dead Sea shore, Limnological Review, no. 2, p. $105-112$.

Wyrzykowski J. (1985). Studia nad oceną walorów krajobrazowych Sudetów dla potrzeb turystyki [Studies on the assessment of landscape values of the Sudetes for the needs of tourism], [in:] Warunki przyrodnicze rozwoju turystycznych form rekreacji, ser. Monografie AWF Poznań, no. 209, pp. 235-249.

Zwoliński A. (1992). Ocena walorów turystyczno-rekreacyjnych sztucznych zbiorników (na przykładzie zbiorników nizinnych) [Evaluation of tourist and recreational values of artificial reservoirs (on the example of lowland reservoirs)], Warszawa: Instytut Turystyki.

Submitted:

26.02.2019
Revised:

15.05.2019
Accepted and published online 07.06.2019 